\title{
POLIGAMI DALAM PERSPEKTIF HUKUM ISLAM (Kajian Tafsir Muqaranah)
}

\author{
M. Ichsan \\ STAI al-Hilal Sigli Aceh \\ J1. Perniagaan No. 10, Keramat Dalam, Sigli Aceh \\ e-mail: abati.arissa_zahid@yahoo.com
}

\begin{abstract}
The controversy of the polygamy issues among scholars occurred very sharply, which is almost difficult to find an agreement. Some contemporary scholars are more likely to disagree with the practice of polygamy. The controversy among the scholars in judging the practice of polygamy in society is the author's reason to examine more specifically the issue in order to get answers to the disputed problems. This research is a library research. It was done by collecting data from books that are related to the problems. This research is descriptive comparative, which studies the comparison of an object, in this case is polygamy according to the Islamic law perspective in the study of the muqaranah (comparison) interpretation. The results of the study is that the controversy of the views of the scholars in terms of polygamy is due to differences in the way of interpreting lafaz amar (marriage orders), namely in the sentence (فحانكوا). Most scholars think that lafaz amar shows to ibahah. Ablu al-Zhabiryah mentioned that the command of marriage in the surah al-Nisa verse 3 means (obligation) to carry out the order of marriage. Al-Tabariy interpreted that the command to marry in the sentence (فحانكوا)

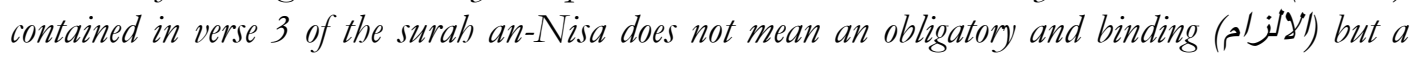
teaching الارشاد and notification This is due to the existence of qarinah which turns away the meaning.
\end{abstract}

Kata kunci: poligami, perspektif, Hukum Islam, Tafsir Muqaranah

\section{PENDAHULUAN}

I slam merupakan agama dan masyarakat dalam ruang lingkup kecil maupun besar. Semua permasalahan yang berkaitan dengan kehidupan masyarakat baik yang berkenaan dengan ibadat, mu'amalat, munakahat dan sebagainya diatur dalam agama yang sempurna tersebut. Salah satu aspek yang diatur oleh Islam dalam kehidupan berumah tangga adalah poligami. Poligami adalah seseorang yang mempunyai dua tua lebih pasangan hidup dalam waktu yang sama. Sebenarnya istilah yang lebih tepat dalam permaslahan poligami adalah "poligini" maksudnya adalah seorang suami mempunyai dua atau lebih isteri dalam waktu yang sama.

Tema poligami atau poligini telah banyak dibahas oleh para ulama sejak zaman dahalu baik kalangan ulama tafsir, maupun ulama fikih. Permasalahan tersebut masih diperdebatkan oleh kalangan ulama hingga saat ini. Hal ini tentu dapat ditemukan terutama dalam kitab-kitab fikih dan kitab tafsir. Hanya saja pandangan yang berkembang selama 
ini cenderung memperkuat pendapat yang membolehkan konsep poligami (ta'adud al-zawat) (Nasaruddin Umar, 2011: 97).

Dimensi kontraversial permasalahan poligami di kalangan ulama terjadi sangat tajam, hampir sulit dipertemukan. Sebahagian ulama mendukung praktek poligami dengan alasan bahwa poligami tersebut adalah fasilitas yang diberikan oleh Allah kepada manusia untuk dapat mencegah sesuatu yang dilarangNya semisal zina. Dalam pandangan ulama tersebut, poligami sebagai salah satu upanya pencegahan terjadinya praktek zina di kalangan masyarakat. Sebahagian ulama lain yang dianggap sebagai ulama kontemporer, lebih cenderung tidak sependapat dengan praktek poligami. Golongan tersebut berpendapat, sesunggunya Islam menganut prinsip monogami yaitu mempunyai isteri satu, golongan ini juga mengecam praktek poligami sebagai perpanjangan tradisi Arab pra-Islam yang memberikan status dominan kepada kaum laki-laki (male-centris) (Nasaruddin Umar, 2014: 130).

Perselisihan pendapat antara ulama dalam menilai praktek poligami di masyarakat, menyebabkan permasalahan tersebut sulit untuk dikompromikan. Karena setiap kelompok juga menggunakan metodologi yang berbeda-beda untuk mengomentari sumber hukum yang dijadikan sebagai landasan hukum dalam permasalahan tersebut. Sehingga menghasilkan produk hukum yang berbeda antara satu golongan dengan golongan yang lain, bahkan bertentangan antara satu sama lainnya.

Kontraversi yang terjadi di kalangan para ulama dalam menilai praktek poligami dalam masyarakat, menarik minat penulis untuk mengkaji lebih spesifik permasalahan tersebut dalam rangka mendapatkan jawaban atas permasalahan yang diperselisihkan. Oleh karena demikian, penulis berupaya untuk mengkaji permasalahan tersebut dengan membandingkan penafsiran antara satu ulama tafsir dengan ulama tafsir lainya yang didapati penafsirannya oleh penulis dalam kitab-kitab tafsir, baik tafsir klasik maupun modern.

Dari latar belakang masalah yang telah digambarkan penulis di atas maka dapat dirumuskan dua rumusan masalah diantaranya adalah:

1. Bagaimana penafsiran ulama terhadap surah al-Nisa ayat 3 mengenai praktek poligami?

2. Apa latar belakang kontrafersial ulama mufasirin dalam permasalahan poligami?

\section{METODE PENELITIAN}

Penelitian ini adalah penelitian kepustakaan (library research) dengan cara mengumpulkan data dari buku-buku atau kitab-kitab yang diteliti dan ada hubungannya dengan permasalahan yang ada yaitu mengenai poligami menurut perspektif hukum Islam kajian tafsir muqaranah.

Penelitian ini bersifat deskriptif komparatif yaitu perbandingan suatu objek yang dalam hal ini adalah poligami menurut persepektif hukum Islam dalam kajian tafsir muqaranah dengan maksud untuk memberikan penjelasan. Selanjutnya dilakukan analisis dari segi metode istinbath hukum dan dari segi kehujjahan dalil-dalilnya sehingga dapat diperoleh suatu kesimpulan yang lebih rajih. 
Penulis menggunakan pendekatan ushulfigh dengan melihat ketentuanketentuan hukum yang ada dengan maksud memberikan penilaian tentang kebenaran dan alasan yang dijadikan sebagai dasar hukum atau hujjah dan juga lebih menekankan terhadap pertimbangan maqasid al-syariah yang releven dengan masa sekarang.

Pengumpulan data dilakukan dengan penelitian kepustakaan untuk memperoleh data-data primer dan sekunder. Peneliti menggunakan metode komparatif, yaitu membandingkan sebuah karya dengan karya-karya yang lain tentang hal yang sama. Dalam penelitian ini, pemikiran ulama klasik dikomparasikan dengan pemikiran ulama modern sehingga dapat diketahui persamaan maupun perbedaan keduanya dan dapat ditarik suatu kesimpulan yang konkrit tentang persoalan yang diteliti.

\section{PEMBAHASAN}

\section{A. Pengertian Poligami}

Kata poligami berasal dari bahasa Yunani, dari kata poly yang berarti banyak dan gamien yang berarti kawin, jika digabungkan akan berarti suatu perkawinan yang banyak (Bibit suprapto, 1990: 61). Bandingkan dengan (Labib MZ, 1986: 15).

Dalam bahasa Arab poligami disebut ta'adud al-zawajah. Poligami diartikan dengan perkawinan yang dilakukan dengan beberapa pasangan pada waktu bersamaan. Dengan demikian poligami itu tidak terbatas hanya dilakukan oleh lelaki, tetapi juga oleh perempuan.
Istilah khusus yang mengacu pada perkawinan seseorang laki-laki dengan beberapa orang perempuan adalah poligini (polyginy) dan yang mengacu pada perkawinan antara seorang perempuan dengan beberapa orang laki-laki adalah poliandri (polyandry). Pengertian poligami yang berlaku di masyarakat adalah seorang laki-laki kawin dengan banyak wanita. Menurut tinjauan Islam poligami mempunyai arti perkawinan yang lebih dari satu, dengan batasan umum yang dibolehkan hanya sampai empat wanita.

Istilah lain yang maknanya mendekati makna poligami yaitu poligini, kata ini berasal dari poli atau polus dalam bahasa Yunai yang artinya banyak, dan gini atau gene artinya isteri, jadi poligini arrtinya beisteri banyak (Badriyah Fahyimi, 2002: 40). Dalam Ensiklopedi Nasional, poligami diartikan suatu pranata perkawinan yang memungkinkan terwujutnya keluarga yang suaminya memiliki lebih dari seorang isteri atau isteri memiliki lebih dari seorang suaminnya.

Istilah yang lebih tepat dalam permasalah di atas sebenarnya adalah "poligini" yaitu seorang suami memiliki dua atau lebih isteri dalam waktu yang sama, sedangkan poligami adalah istilah yang digunakan untuk menyebut perkawinan yang lebih dari satu, baik laiki-laki atau perempuan. Istilah poligami sering dipakai untuk mengacu kepada poligini, karena praktek ini sering dilaksanakan dalam masyarakat dibandingkan dengan poliandri (seorang isteri mempunyai suami dua orang dalam waktu yang 
sama). Selanjutnya penulis menggunakan istilah poligami untuk menyebut seorang suami yang memiliki lebih dari seorang isteri.

\section{B. Poligami dalam Hukum Islam}

1. Dasar Hukum Poligami Al-Qur'an surah al-Nisa ayat 3

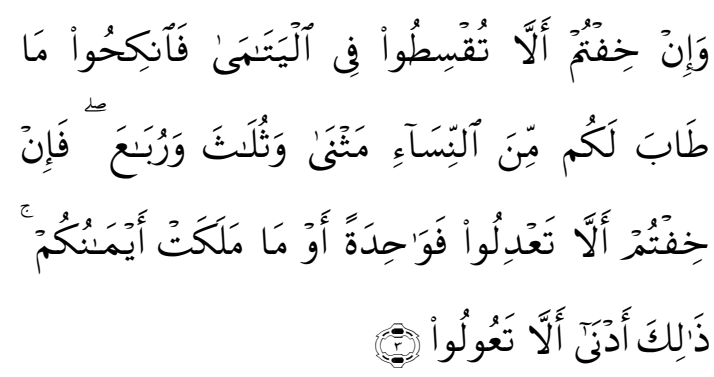

"Dan jika kamu takut tidak akan dapat berlaku adil terhadap (hakhak) perempuan yang yatim (bilamana kamu mengawininya), maka kawinilah wanita-wanita (lain) yang kamu senangi: dua, tiga atau empat. Kemudian jika kamu takut tidak akan dapat berlaku adi, maka (kawinilah) seorang saja, atau budakbudak yang kamu miliki. Yang demikian itu adalah lebih dekat kepada tidak berbuat aniaya." Q.S. al-Nisa [4]: 3)

Ayat di atas, merupakan bagian dari surah al-Nisa. Permulaan surah ini dimulai dengan perintah untuk bertakwa kepada Allah yang telah menjadikan manusia dengan berpasang-pasang dan perintah memelihara silaturrahmi antar sesama manusia. Secara sosiologis ayat ini turun untuk merespon kebiasaan suku bangsa Arab Jahiliyah yang membolehkan seorang laki-laki menikah lebih dari empat orang wanita, enam dan sepuluh. Dalam hal ini, kaum Jahiliyyah berpendirian bahwa" tidak ada satu orang pun yang dapat melarang kaumnya untuk menikah sebagaimana yang dilakukan si fulan dalam hal jumlah wanita yang dinikahinya (Muhammad bin Jarir bin Yazid bin Khalid al-Tahabariy, 1405 H: 233).

Dalam budaya yang dipraktekkan tersebut, kaum Jahiliyah tidak merasa terbebani sama sekali untuk berlaku adil terhadap isterinya yang telah dinikahi tersebut, baik di antara para isteri terdapat anak yatim yang dulunya ia asuh atau tidak.

Dalam masyarakat Jahiliyah pada saat itu juga sudah menjadi tradisi yang dianggap biasa apabila menggunakan harta anak yatim yang diasuhnya sebagai biaya pernikahannya dengan perempuan lain. Bukan hanya sampai di situ, juga tidak dipandang sebagai "cacat" kalau wali yang mengasuh si anak yatim perempuan, mengambil keuntungan dari anak yatim perempuan tersebut dengan menjadikanya sebagai pelacur. Dengan turunnya alQur'an surah al-Nisa ayat 3 di atas, merupakan jawaban terhadap ketidakadilan perlakuan orang-orang Jahiliyah juga membatasi kebolehan untuk menikahi hanya sampai empat orang perempuan dalam waktu yang bersamaan (Abd al-Rahman bin 'Ali bin Muhammad al-Jauziy, 1404 H: 5).

Penggunaan huruf (ما) pada kalimat ما طاب لكم, menunjukkan kata sambung isem maushul, dan dalam ayat tersebut tidak menggunakan huruf من. Sementara kata(مام)itu sendiri biasanya digunakan untuk 
menjelaskan selain manusia. AlThabary (W. 310 H) menjelaskan bahwa makna sesunguhnya dari ayat tersebut adalah "nikahlah dengan nikah yang baik" hal itu didukung oleh berbagai riwayat, di antaranya dikemukakan oleh Mujahid (W. 104 H). Pada ayat di atas terdapat lafaz amar (perintah menikah) yaitu pada kalimat (فانكحو ) mayoritas ulama berpendapat bahwa lafaz amar menunjukkan kepada pada ibahah (Mustafa alKinn, 1985: 300). Untuk melaksanakan yang diperintahkan tersebut selama tidak ada qarinah artinya perintah yang tercantum dalam ayat di atas bukan wajib dan bukan pula sunnat, walaupun ada yang berpendapat wajib maka maksudnya adalah wajib membatasi jumlah isteri bukan kewajiban untuk menikahi isteri. Ahlu al-Zhahiryah menyebutkan bahwa lafazh amar (perintah menikah) dalam surah alNisa ayat 3 di atas berarti (kewajiban) untuk melaksanakan perintah menikah, karena golongan tersebut memahami ayat $\mathrm{di}$ atas secara sharih .

Menurut al-Tabariy (W. $310 \mathrm{H}$ ) perintah menikah pada kalimat yang terdapat dalam ayat 3 surah an-Nisa tersebut tidak bermakna wajib dan mengikat (الالزام) akan tetapi bermakan pengajaran dan pemberitahuan الارشاد demikian disebabkanadanya qarinah yang memalingkan makna tersebut, yaitu frase "dan jika kamu takut tidak akan dapat berlaku adil terhadap (hakhak) perempuan yang yatim".
Walaupun bentuk kata dalam frase tersebut menunjukkan perintah, akan tetapi dengan adanya qarinah ini ia bermakna larangan terhadap pernikahan poligami yang dikhawatirkan akan mencelakan para isteri tersebut, farse di atas tidak bermakna perintah untuk melakukan poligami. Oleh karene demikian, makna ayat di atas "jika khawatir tidak akan dapat berlaku adil terhadap perempuan yatim dan perempuan bukan yatim, maka janganlah kamu menikah kecuali pernikahan halal yang kamu merasa yakin tidak akan mencelakai para isteri-isterimu satu sampai empat orang.

Di dalam Bahasa Arab, juga termasuk dalam al-Qur'an, sudah menjadi kebiasaan menggunakan kelimat perintah dengan makana larangan dan ancaman al-wa'du wa al-wa'id. Hal itu misalnya dapat dilihat dalam surah al-Kahfi (18) ayat 29:

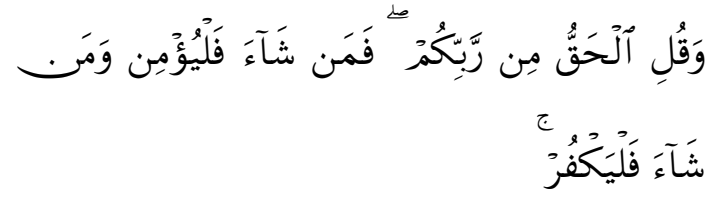

"Dan Katakanlah: "Kebenaran itu datangnya dari Tuhanmu; Maka Barang siapa yang ingin (beriman) hendaklah ia beriman, dan Barangsiapa yang ingin (kafir) biarlah ia kafir". (Q.S. al Kahfi [18]: 29)

Oleh karena itu, seperti dijelaskan al-Thabariy, dan penulis lebih condong dengan pendapatnya. Sesunggunya ayat al-Qur'an tersebut memberikan pemahaman terbalik. 
Maka, makna ayat tersebut, apabila khawatir tidak akan berlaku adil dengan menikahi empat orang, maka nikahilah tiga orang perempuan saja. Kalau dikhawatirkan tidak dapat berlaku adil dengan menikahi tiga orang perempuan, nikahilah dua orang saja. Jika masih dikhawatirkan dengan menikah dua orang perempuan maka nikahilah satu orang perempuan saja. Akan tetapi, kalau dikhawatirkan tidak akan berlaku adil dengan menikahi satu orang perempuan saja (merdeka), maka cukuplah bagimu budak perempuan yang kamu miliki.

Makna perintah menikah setelah فا syarat yang terdapat di atas adalah "larangan" hingga ayat tersebut berarti "jika kamu khawatir" wahai para wali anak yatim, untuk tidak berlaku adil dalam menafkahinya. Dengan hanya memberikan nafkah yang sama dengan perempuan lain, maka jangan dinikahi anak yatim terebut, tetapi nikahilah perempuan lain yang telah dihalalkan oleh Allah untukmu satu sampai empat orang. Jika masih dikhawatirkan akan berbuat aniaya kepada perempuan lain yang telah dinikahi lebih dari satu orang tersebut, dengan tidak berbuat adil, maka nikahilah hanya seorang saja atau nikahilah budak perempuan yang dimilikinya.

\section{Analisa Komperatif Pandangan Ulama Tentang Hukum Poligami}

Sebelum penulis menganalisis padangan ulama tentang hukum poligami, perlu dijelaskan terlebih dahulu bahwa hukum poligami sangat berkaitan erat dengan hukum melaksanakan pernikahan. Para ulama fikih menyebut bahwa hukum menikah meliputi kelima hukum taklifi, yaitu: wajib, sunnat, mubah, makruh dan haram (Wizarat al-Awqaf wa al-Syuun al-Diniyah, 2002: 210). Hukum menikah tentu akan berubah-ubah, tergantung kondisi dan keadaan orang yang akan melaksanakan pernikahan tersebut.

Hukum nikah menjadi wajib, bagi orang yang mempunyai hasrat tinggi untuk menikah karena dorongan syahwatnya bergejolak dan ia mempunyai kemampuan ekonomi yang cukup, sehingga dikhawatirkan ia akan terjerumus kedalam perzinaan apaliba ia tidak melaksanakan pernikahan tersebut. Adapun bagi orang yang mempunyai syahwat, dan juga mempunyai harta, tetapi tidak khawatir terjerumus dalam maksiat semisal perzinaan maka baginya hukum nikah adalah sunnat. Nikah hukumnya mubah bagi orang yang mempunyai syahwat, tetapi tidak mempunyai harta. Atau bagi orang yang mempunyai harta tetapi tidak mempunyai syahwat. Nikah hukumnya makruh bagi orang yang tidak mempunyai harta dan tidak pula mempunyai keinginan untuk menikah (lemah syahwat), sedangkan bagi orang yang merasa dirinya tidak mampu bertanggung jawab dan akan menelantarkan isteri, anak maka baginya haram untuk menikah. (Wahbah al-Zuhaily, 2002: 31) dan (Ibnu Qudamah, n.d: 341).

Apabila dilihat hukum poligami berdasarkan al-Qur'an surah al-Nisa ayat 3: 


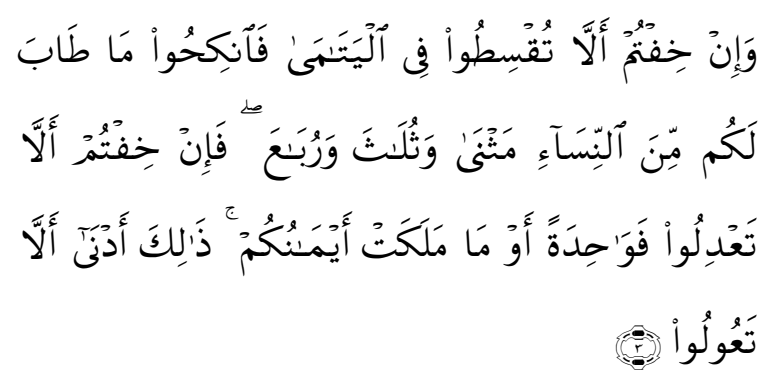

"Dan jika kamu takut tidak akan dapat berlaku adilterhadap (hak-hak) perempuan yang yatim (bilamana kamu mengawininya), maka kawinilah wanitawanita (lain) yang kamu senangi: dua, tiga atau empat. Kemudian jika kamu takut tidak akan dapat berlaku adi, maka (kawinilah) seorang saja, atau budakbudak yang kamu miliki. yang demikian itu adalah lebih dekat kepada tidak berbuat aniaya".

Penulis lebih condong mengatakan bahwa perintah yang terdapat dalam ayat tersebut tidak bermakna wajib dan mengikat, akan tetapi bermakna pengajaran dan pemberitahuan. Hal itu disebabkan adanya qarinah yang memalingkan makan tersebut, yaitu kaliamat:

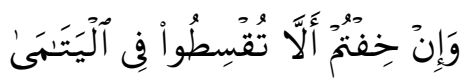

“dan jika kamu takut tidak dapat berlaku adil terhadap (hak-hak) perempuan yang yatim", walaupun bentuk katanya adalah perintah, akan tetapi dengan adanya qarinah ini maka bermakna larangan terhadap pernikahan larangan poligami yang dikhawatirkan akan mencelakan para isteri, bukan bermakna perintah untuk melakukan poligami. Makna ayat tersebut adalah "jika kalian khawatir tidak akan berlaku adil terhadap para perempuan yatim dan perempuan bukan yatim, maka janganlah dinikahi kecuali pernikahan halal yang kamu merasa yakin tidak akan mencelakai para perempuan tersebut, satu sampai empat orang".

Berdasarkan ayat di atas, pada dasarnya hukum poligami adalah mubah dan hukum mubah tersebut bisa berbeda pada setiap orang yang akan melaksanakannya sesuai kondisi masing-masing, yaitu mashlahah (mengambil mamfaat dan menolak mafsadah). Prinsip yang harus diterapkan dalam penerapan maslahah adalah menolak mafsadah lebih diutamakan dari pada mengambil manfaat, prinsip ini telah dirumuskan dalam qaidah درء المفاسد اولي علي جلب yang artinya: "Menolak mafsadah lebih diutamakan dari mengambil maslahah" (Muhammad Ali Ahmad al-Nadwi, 2000: 207).

Secara umum maslahah yang dapat diperoleh dengan poligami adalah terpeliharanya suami dari perzinaan. Sedangkan mafsadah yang akan muncul jika pintu poligami ditutup adalah perzinaan dan monogami serial. Monogami serial akan berimplikasi pula terhadap penelantaran mantan isteri dan anak (Ahmad Fedyani Saifuddin, 2007: 2).

Menurut hemat penulis banyak hal yang akan muncul akibat perkawinan poligami yang dapat diasumsikan sebagai sisi negatif (mafsadah), diantaranya adalah: poligami mengakibatkan permusuhan di antara para isteri sehingga suasana rumah tangga tidak harmonis, perselisihan antara isteri yang dimadu sering merambat kepada anak, sehingga kebahagiaan rumah tangga jadi terganggu, adanya tekanan 
psikologis terhadap isteri pertama yang merasa diduakan cintanya, dan tekanan secara sosial, karena asumsi masyarakat yang selalu mempermasalahkan pihak perempuan sebagai biang keladi dari praktek poligami, dan berbagai asumsi-asumsi lainya dianggap akan terjadi apabila praktek poligami terjadi dikalangan mayarakat.

Atas dasar pertimbangan maslahah di atas hukum poligami bisa meliputi semua hukum taklify yaitu wajib, sunnat, mubah, haram, dan makruh. Poligami menjadi wajib apabila kebutuhan sangat mendesak, misalnya dalam kondisi suami mempunyai dorongan seks yang luar biasa, sehingga akan mengakibatkan terjadinya perzinaan. Di sisi lain suami juga dapat berbuat adil kepada isterinya, baik dari aspek materi dan biologis. Poligami menjadi sunnah hukumnya apabila suami mempunyai dorongan seks yang luar biasa, apabila tidak malakukan poligami akan menyebabkan ia terjerumus pada perzinahan, dan suami tersebut juga berpotensi untuk mempnyai keturunan. Dari sisi lain suami tersebut juga dapat berbuat adil kepada isteri-isterinya dan anak-anaknya, baik dari aspek materi maupun bathiny. Poligami menjadi haram hukumnya apabila suami melakukan poligami hanya berorientasi pada pelampiasan syahwat belaka dan tidak memperhatikan kondisi dan kemampuan materi dan mental. Ia tidak yakin bahwa dirinya dapat berbuat adil kepada isteri-isterinya. Apabila suami yakin bahwa dirinya tidak mampu untuk memenuhi hakhak isteri, apalagi sampai menyakiti dan mencelakakannya poligami hukumnya haram.

Jadi, dari paparan yang telah disampaikan pada pembahasan di atas maka hukum dari poligami tersebut tidak bertumpu pada adanya nash, melainkan pada situasi kondisi. Predikat hukumnya akan mengikuti kondisi ruangan dan waktu. Prinsipnya adalah keharusan untuk selalu merujuk prinsip-prinsip dasar syariah yaitu keadilan, membawa kemaslahatan dan tidak mendatangkan kemudharatan.

\section{PENUTUP}

Dari keseluruhan pembahasan yang telah dipaparkan, maka dapat disimpulkan tiga kesimpulan sebagai hasil dari penelitian dari penulisan ini sebagai berikut:

1. Tafsiran surat al-Nisa ayat 3 adalah, apabila dikhawatirkan tidak akan berlaku adil dengan menikahi empat orang, maka nikahilah tiga orang perempuan saja. Dan apabila dikhawatirkan tidak dapat berlaku adil dengan menikahi tiga orang perempuan, nikahilah dua orang saja. Jika masih dikhawatirkan dengan menikah dua orang perempuan maka nikahilah satu orang perempuan saja. Akan tetapi, kalau dikhawatirkan tidak akan berlaku adil dengan menikahi satu orang perempuan (merdeka), maka cukuplah bagimu budak perempuan yang kamu miliki.

2. Penyebab terjadinya kontraversi pandangan para ulama dalam hal poligami adalah karena perbedaan cara pada dalam menafsirkan lafaz amar (perintah menikah) yaitu pada kalimat mayoritas ulama berpendapat 
bahwa lafaz amar menunjukkan kepada hukum ibahah yaitu ketentuan Allah yang mengandung kebolehan memilih antara melakukan atau meninggalkannya. Ahlu al-Zhahiryah menyebutkan bahwa lafazh amar (perintah menikah) dalam surah alNisa ayat 3 berarti (kewajiban) untuk melaksanakan perintah menikah, karena golongan tersebut memahami ayat di atas secara sharih lafaznya. Menurut al-Tabariy perintah menikah pada kalimat (فانكحوا) yang terdapat dalam ayat 3 surah an-Nisa tidak bermakna wajib dan mengikat (الالزام) akan tetapi bermakna pengajaran الارشاد) dan pemberitahuan الاعلام. Hal demikian disebabkan adanya qarinah yang memalingkan makna tersebut.

3. Hukum poligami tidak bertumpu pada adanya nash, melainkan pada situasi kondisi. Predikat hukumnya akan mengikuti kondisi ruangan dan waktu. Prinsipnya adalah keharusan untuk selalu merujuk prinsip-prinsip dasar syariah yaitu keadilan, membawa kemaslahatan dan tidak mendatangkan kemudharatan.

\section{DAFTAR KEPUSTAKAN}

al-Diniyah, Wizarat al-Awqaf wa alSyuun. 2002. al-Mausu'ah al-Fiqhiyah, Kuwait: Wizarat al-Awqaf wa alSyuun al-Diniyah, Juz 41.

al-Jauzi, Abd al-Rahman bin 'Ali bin Muhammad. n.d. Zad al-Masir. Beirut: al-Maktab al-Islamiy.
al-Kinn, Mustafa. 1985. Atsar Al-Ikhtilaf fi al-Qawaid al-Ushuliyah fi Ikhtilaf alFuqaha. Beirut: Muasasah al-Risalah.

al-Nadwi, Muhammad Ali Ahmad. 2000. al-Qawa'id al-Fighiyah. Damsyiq: Dar al-Qalam.

al-Tahabariy, Muhammad bin Jarir bin Yazid bin Khalid. n.d. Jami' al-Bayan "an Ta"wil ayat al-Qur;an. Ed. Bairut: Dar al-Fikiri, Juz. 4

al-Zuhaily, Wahbah. 2002. Figh al-Islami wa al-Adilatuhu. Damaskus: Dar al-Fikri.

Fahyimi, Badriyah dkk. 2002. Isu-isu Jender dalam Islam. Jakarta: PSW UIN Syarif hidayatullah.

Ibnu Qudamah .n.d. Al-Mughny. Kairo: Dar Al-Hadis.

Saifuddin, Ahmad Fedyani. 2007. Poligami dalam Perspektif Sosial Budaya.' Suatu Catatan Teoritis Dipresentasikan. In Poligami dalam perspektif social, ekonomi,dan budaya. Jakarta: Lembaga Demografi Fakultas Ekonomi Universitas Indonesia.

Suprapto, Bibit. 1990. liku-liku poligami. Yogyakarta: Al-Kausart.

MZ, Labib. 1986. Pembelaan Umat Muhammad. Surabaya: Bintang Pelajar.

Umar, Nasaruddin. 2011. Fikih Wanita Untuk Semua. Jakarta: Serambi Ilmu Semesta, Cet. I.

2014. Ketika Fikih Membela Perempuan. Jakarta: PT Elex Media Komputinda. 
